HENARE KING

\title{
Ko Kupe Te Tupuna
}

The book "The Tail of the Fish" was publised in 1968 and written by a Te Aupouri kuia, Matire Kereama (nee: Hoeft) of the far north of Aotearoa, New Zealand. I grew up with this book as my grandmother would read the stories to me at bedtime. Although my comprehension of each story was very vague and unrelatable to my life at that time, today, I find myself totally absorbed by the historical content and knowledge encapsulated in each chapter.

I completed a Masters of Applied Indigenous Knowledge at Te Wananga o Aotearoa in 2017, entitled; Tales of the singing fish: He tangi wairua. I compsed twelve waiata (Maori songs) of which ten of the waiata was information extracted from ten chapters of the book. The other two waiata were composed specifically for my people of the Te Rarawa tribe, namely, Ahipara.

The whakatauki "e kore e ngaro, he takere waka nui" (we will never be lost; we are the hull of a great canoe) demonstrates the amazing srength of the ancient sea voyager "Kupe" who discovered Aotearoa, New Zealand, in the deep South Pacific Ocean, Te Moana nui ā Kiwa. Kupe was aware of the growing population on their home islands so his nepehw Nukutāwhiti shared his concerns with Kupe about the overcrowding of the island and wanted to take his family to the new found land of Aotearoa.

Kupe agreed and offered his waka (canoe) Ngātoki-matāwhāorua for the long voyage across the great ocean of the South Pacific seas. The canoe transported a number of people across the ocean with a broad wave ahead of it named Ngarunui and a long wave behind them named Ngaruroa. The canoe arrived in Aotearoa and headed to the nearest point and when the voyagers got closer to the shoreline a great wave seemed to come stratight toward them. Quickly the wave Ngarunui which had come all the way ahead of the canoe sent the new wave back. 
The wave called Ngarupaewhenua guided the canoe safetly into Hokianga Habou

Nukutāwhiti and the newcomers settled at Ngārongotea and later crossed to Pākanae near Opononi where their descendants have erected a memorial stone in honour of their great ancestor's bravery in facing the unknown to search for a better home. At Pākanae, Nukutāwhiti and his wife Kahuoterangi had their first son. They called him Ngarunui after the broad wave which had guided them safely to their destination.

Ko Kupe te tūpuna

Ka haere ki runga i te Moana nui ā Kiwa

Kua kitea kua rongo kua oho

Ko Aotearoa

Ko Ngarunui

Ko Ngaruroa

Ko Ngarupaewhenua

Ngā kaitiaki

O Ngātokimatāwhāorua

E kore e ngaro he takere waka nui e 